$$
\text { DOE/CE/2830/-T T }
$$

\title{
RENEWABLE ENERGY AND \\ UTILITY REGULATION
}

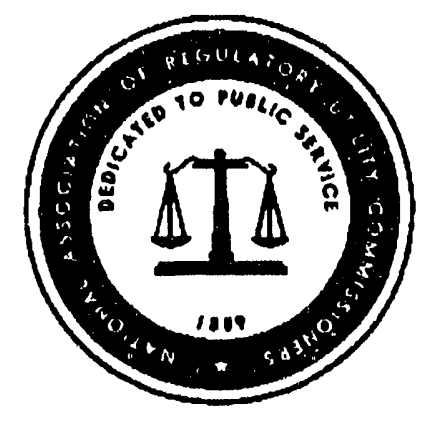

\author{
APRIL 10, 1991 \\ COMMITTEE ON \\ ENERGY CONSERVATION
}

SUBCOMMITTEE ON

RENEWABLE ENERGY

\section{National Association of Regulatory Utility Commissioners Room 1102 ICC Building; P.O. Box 684 Washington, D.C. 20044}

Telephone No. (202) 898-2200 
$\mathrm{DOE} / \mathrm{CE} / 28301--\mathrm{T} 6$

DE92 013626

\section{DISCLAIMER}

This report was prepared as an account of work sponsored by an agency of the United States Government. Neither the United States Government nor any agency thereof, nor any of their employees, makes any warranty, express or implied, or assumes any legal liability or responsibility for the accuracy, completeness, or usefulness of any information, apparatus, product, or process disclosed, or represents that its use would not infringe privately owned rights. Reference herein to any specific commercial product, process, or service by trade name, trademark, manufacturer, or otherwise, does not necessarily constitute or imply its endorsement, recommendation, or favoring by the United States Government or any agency thereof. The views and opinions of authors herein do not necessarily state or reflect those of the United States Government or any agency thereof. 


\section{ACKNOWLEDGMENT}

In 1989, the National Association of Regulatory Utility Commissioners Energy Conservation Committee formed a Subcommittee on Renewable Energy. The Honorable Henry G. Williams, Public Service Commissioner from the State of New York, chairs the Subcommittee. With the assistance of Mike Foley, NARUC Director of Financial Analysis, Commissioner Williams oversaw this project to assess experience and ideas on practical development of renewable energy technologies.

With a supporting grant from the U.S. Department of Energy, NARUC selected the firm R\&C Enterprises to conduct a workshop on development of renewable energy in the market and submit findings and recommendations to NARUC's Renewable Energy Task Force. The Solar Energy Research Institute hosted the workshop at its facilities in Golden, Colorado, and offered its insights on market potential of renewable energy.

Carlo LaPorta of R\&C Enterprises and R\&C Consultant, Mr. David Moskovitz, organized the project, managed the workshop and prepared this report. They received tremendous assistance from the twenty-eight workshop attendees (including three State public utility commissioners) who represented the regulatory community, utilities, renewable energy companies, and several institutions. These individuals did much more than attend the workshop; they responded to advance questionnaires, searched for relevant material from their companies or states, and contributed a wide range of perspectives and experience to the meeting.

In all, this group brought NARUC more than 300 years of direct experience with renewable energy. The following report extracts the best insights and ideas of those who contributed to it, and stands as an acknowledgment of their contribution to a more creative and sound energy future. Their names are listed in the appendix.

\section{NARUC Subcommittee on Renewable Energy}

The Hon. Henry G. Williams of New York; Chair

The Hon. Renz Jennings of Arizona

Mr. David Morse of California

Mr. Gordon Dunn of Iowa

Mr. Bill Eastlake of Idaho 


\section{FOREWORD}

Utility regulators are encountering an escalation in public concerns about environmental impacts of fossil energy consumption that transcends the "not-in-my-backyard" syndrome related to power plant siting. Time magazine highlighted this concern when it made Earth its "Planet of the Year" in late 1988. In the mean time, federal government interest in energy policy has been focused on rising U.S. imports of petroleum and their effect on national energy and economic security. Spurred by the sudden petroleum price rise due to Middle East politics in August 1990, and the threat of a recession due to higher energy costs, the federal government has also suddenly reawakened to broader energy policy issues. As they make energy supply decisions and consider the impacts of those decisions on the economy and the environment in these new circumstances, utility regulators will be asked to give more consideration to the potential contribution of renewable energy resources.

Are renewable energy systems affordable, practical and reliable? Who manufactures and installs them? Can these technologies economically shoulder a larger share of demand for energy in a cleaner, more sustainable manner that helps preserve the environment for future generations? Can these technologies significantly reduce dependence of the United States on foreign sources of petroleum, now at more than fifty percent? Or is the national energy security issue really outside the realm of the electric utility regulator? After a period of scant attention to renewable energy resources, these questions are being asked again.

Cutbacks in government research and development funding and elimination of many of the financial incentives used in the late 1970s and early 1980s to spur private investment in renewable energy presented an image that these systems were just highly exotic technologies whose future contribution was decades away. This perception is just not accurate. Renewable energy technologies contribute more than eight percent of the energy the United States uses, and market growth for several technologies has continued despite a period of falling prices for fossil fuels. The false perception has persisted because it has been more difficult to stay in touch with developrnents in the renewable energy field due to a lack of information. Staying informed about capability and performance of these technologies is more difficult because the industry is developing rapidly and lower government budgets for renewable energy also reduced the flow of information. To summarize, over the last five years, limited national attention to energy issues curtailed policy maker interest in development of renewable energy resources.

This situation is on the verge of changing. The federal government has increased funding for renewable energy $R \& D$ for the first time in ten years. Today, answers available to basic and detailed questions about renewable energy are much better than those fifteen years ago when a crisis atmosphere stimulated hugh interest in renewable energy. Now, much wider experience with commercially deployed renewable energy systems and market successes in various states furnish valuable insights and policy lessons. Responding to this change, he National Association of Regulatory Utility Commissioners has recognized that its members need a new assessment of renewable energy potential and guidance on policies and techniques that will raise the contribution of renewable energy resources in the nearer term. 
The brief investigation of renewable energy resources and public policy reported in this document addresses key questions about technical and economic potential of renewable energy resources. Seeking to furnish insights for State regulators, it stresses regulatory impediments to more rapid deployment of renewable energy systems. Besides informing regulators about the current status of renewable energy and how utility regulation has affected deployment of these technologies, another key objective is to recommend a new structure of cooperation in renewable energy between the National Association of Regulatory Utility Commissioners and U.S. Department of Energy. Both these organizations want to expand understanding of government and private sector initiatives and help utility regulators bring economical, safer, and more secure energy supplies to consumers. Considering both the pitfalls as well as the gains that have been made, this document suggests a role for utility regulators who wish to see their states raise the rate dt which they shift to new, clean, in-state sources of energy supply. 


\section{RENEWABLE ENERGY AND UTILITY REGULATION \\ A REPORT PREPARED FOR THE \\ NARUC SUBCOMMITTIEE ON RENEWABLE ENERGY}

\section{TABLE OF CONTENTS}

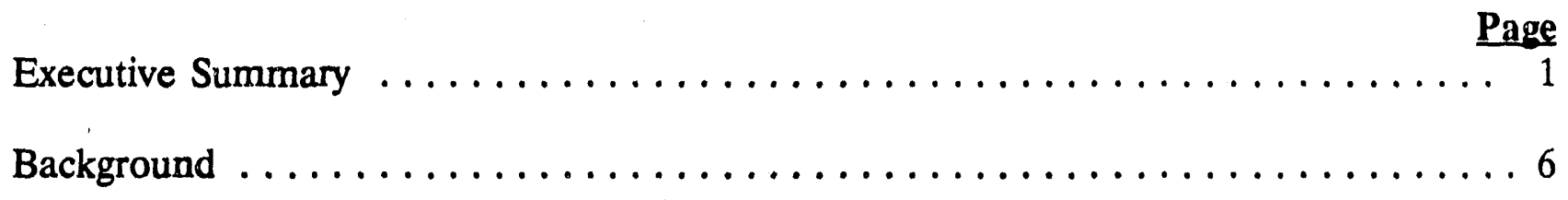

Section I Renewable Energy Contributions, Costs and Potential $\ldots \ldots \ldots \ldots \ldots 8$

Current Contribution $\ldots \ldots \ldots \ldots \ldots \ldots \ldots \ldots \ldots \ldots \ldots \ldots$

Performance of Dispersed Renewable Energy Systems $\ldots \ldots \ldots \ldots \ldots \ldots$

Costs of Renewable Energy Technologies $\ldots \ldots \ldots \ldots \ldots \ldots \ldots \ldots$

Resource Potential . . . . . . . . . . . . . . . . . . . . . 17

State-by-State Assessment of Renewable Energy Use . . . . . . . . . . . 19

Section II Factors Affecting Development of Renewable Energy Resources . . . . . 24

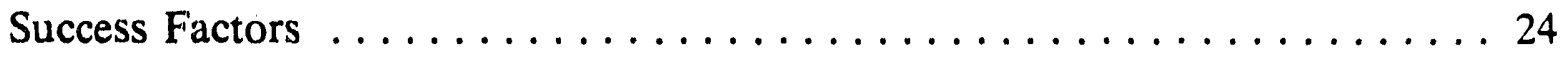

Key Barriers Hindering Renewable Energy Development $\ldots \ldots \ldots \ldots \ldots 30$

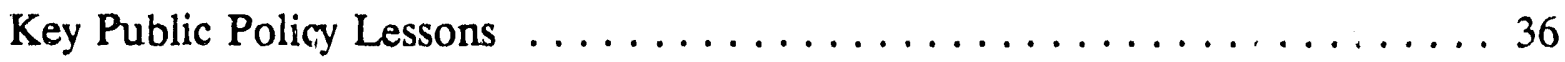

Section III A Renewable Energy Agenda for NARUC $\ldots \ldots \ldots \ldots \ldots \ldots \ldots$

Program Item Recommendations $\ldots \ldots \ldots \ldots \ldots \ldots \ldots \ldots \ldots \ldots$

Adjunct Experts Worlshops ......................42

Other Recommendations $\ldots \ldots \ldots \ldots \ldots \ldots \ldots \ldots \ldots \ldots \ldots \ldots$ 


\section{SUBCOMMITTEE ON RENEWABLE ENERGY \\ NATIONAL ASSOCIATION OF REGULATORY UTILITY COMMISSIONERS}

\section{EXECUTIVE SUMMARY}

This report summarizes the results of a joint project on renewable energy of the National Association of Regulatory Utility Commissioners (NARUC) and the U.S. Department of Energy. NARUC'S Task Force on Renewable Energy conducted a review of the current state of renewable energy technologies to evaluate their potential and extract key policy lessons from experience already gained in deployment of these technologies in numerous states.

The main focus of this effort has been to clarify how utility regulators affect the development of renewable energy resources. The goal of the project was twofold: 1) identify the factors that have led to success or failure of renewable energy technologies in various energy markets, and 2) to develop an agenda on renewable energy and utility regulation for NARUC and the Department of Energy.

This report consists of three sections. Sections I and II explain the basis for the detailed agenda that is described in Section III.

I. Renewable Energy Contributions, Costs and Potential

II. Factors Affecting Development of Renewable Energy Resources

III. A Renewable Energy Agenda for NARUC

\section{Our fundamental conclusions are threefold:}

1. Renewable energy resources have demonstrated competitiveness, and are making a substantial contribution to energy supply; but, very large untapped potential remains. Both centralized and dispersed renewable energy systems can play a major role in providing least cost energy resources with minimal environmental impact.

2. The key to the development of these resources lies in the hands of the states, and in particular, with state utility commissioners.

3. The federal government can undertake initiatives that will accelerate development of renewable energy resources.

Renewable energy already contributes more than eight percent to nationa' energy supply.

From 1980 to 1988 , the electricity generating capacity of non-hydroelectric renewable energy technologies had risen from about 1100 megawatts to more than 9,500 megawatts. In addition, more than a million dispersed on-site renewable energy systems have been installed in the United States. The Department of Energy estimates that by 1988, renewable 
energy contributed 6.7 quadrillion Btus (Quads) to national energy supply, which amounted to 8.2 percent. In eight states, the energy contribution from renewable energy resources, excluding hydropower, is already between 12 and 18 percent of total energy supply.

The cost and performance of renewable energy resource technologies have improved substantially in the last decade.

A most important conclusion we reach is that renewable energy technologies have come a long way. At one time oversold, they are now under appreciated. Deployed wind, solar thermal and biomass technologies have exhibited most dramatic improvements. Over the 1980 s, the installed costs of wind turbines have fallen from over $\$ 3000$ per kilowatt to $\$ 1000$. The output per installed kilowatt of capacity has risen from 200 kilowatt hours per year to 1,300 kilowatt hours per year, and the best new wind energy installations in ideal locations are demonstrating capacity factors of 30 percent.

A similar track record exists for solar thermal electric facilities. The first commercial solar thermal electric power plants came on line in 1984, with a capacity of 14 megawatts. The levelized cost of power for this Luz International SEGS I plant was 24 cents per kilowatt hour. The levelized 30-year cost for its latest 80 megawatt plant is reported to be 8 cents per kilowatt hour. The installed capital cost for plants in the early 1990 s is projected to be $\$ 2300$ per kilowatt, about 50 percent of the cost for the first plant built in 1984 . With their co-fired natural gas component, SEGS plants have demonstrated capacity factors of 97 percent during summer peak power periods, and 80 percent during summer mid-peak periods. Even without cost reductions from economies of scale and technical improvements, today, this resource is competitive with non-renewable plants in large areas of the country with high insolation values.

Biomass energy systems have also demonstrated great progress. Currently, new 15 to 25 megawatt wood-fired power plants in the Northeast are competitive with any conventional base load system. According to the National Wood Energy Association, by 1988, 3,800 megawatts of wood-fired electric power generation were on line at 296 facilities in 40 states. This is an increase from approximately 200 megawatts in 1980, when there were less than a dozen utilities in the U.S. with wood-fired power plants. The biomass contribution has grown rapidly, considering that it was only in 1983, that Washington Water Power Company brought on line the first modern-day wood fired electric power plant in Kettle Falls, Washington.

The obvious conclusion is that renewable energy systems have made tremendous strides, many systems are currently competitive, and new technologies coming into the market will further expand their competitiveness. Most state utility commissions are unaware of this significant progress or the factors underlying successful use of renewable energy resources.

\section{Development of Renewable Energy Resources is Occurring in an Uneven Pattern}


In a few states, renewable energy resources have developed reasonably well, competing with more traditional power supply sources and supplying a substantial fraction of all new resources coming on line. In other states, even those with abundant resource bases, the development of renewable energy has flagged.

The explanation is straightforward. Strong and consistent state public utility commission implementation of the Public Utility Regulatory Policies Act of 1978 (PURPA) is a must. Without attention from regulators, cost-effective resources will not be developed.

In general, renewable energy resource development has occurred reasonably well in regulatory environments where qualifying facilities have developed well. However, even with relatively successful implementation of PURPA, failure to give special attention to the needs and characteristics of renewable energy resource technologies will mean these resources will go untapped, even though they are more cost effective and more environmentally benign than the resources being developed.

Tax incentives or subsidies for renewable resources can certainly help spur the development of these resources, but history has demonstrated that such incentives are less important than state action. When federal tax credits existed, qualifying facilities in general and renewable energy resources in particular, fared well only in selected states. To be sure, local and regional needs and resource availability provide a partial explanation; however, in leading states, development of renewable resources has continued after termination or curtailment of federal tax incentives.

The adoption and implementation of least cost planning processes will assist development of renewable energy resources.

Planning processes which fail to search for the widest range of potential resources will probably not find anything but the most conventional power supply options. One of the hallmarks of least-cost planning is the effort to gather information on a full range of demand and supply-side options. The least cost planning process then identifies the mix of various options that provides consumers with energy services in the least costly manner. In some States, cost is defined broadly to include environmental and other externalities. Planning processes which fail to examine the full breadth of available options will almost certainly result in more costly energy system services.

The weak link in the least-cost planning process is the availability of up-to-date information on cost and performance of renewable energy technologies.

The value of the results of a least cost plan is highly dependent on the col leteness and accuracy of the information used to develop the plan. If old information understates the renewable energy resource or overstates the cost of renewable energy, the least cost plan will call for a minor role for renewable energy technologies. This is also true in states that rely on bidding and other mechanisms to develop resource plans. Utilities or regulators with 
inaccurate information about renewable energy will reject renewable based bids or claims by vendors. Current, reliable, regionally specific information on the cost, availability and performance of renewable energy resources must be made available to state regulators.

A successful program for renewable technologies requires regulatory action that is aware of the character and needs of renewable energy technologies.

Existing state regulatory rules and practices unintentionally produce biases against renewable energy resources. As a result, renewable resources often fail in competition with more traditional resources even though they are more cost-effective. Price levels that do not reflect the operational characteristics of renewable energy systems, payment patterns and terms, and rigid bidding rules, are just a few examples of problem areas. Knowledge of how these factors and others affect the viability of renewable energy resources has to be brought to the attention of regulators and utilities.

Federal government action in many areas will help, but no action is likely to produce a faster and greater payback than providing NARUC with needed support.

Federal support for renewable energy can take many forms. Highlighting the potential of renewable energy in the new National Energy Strategy, reconciling tax policies with energy and environmental goals, and increasing renewable energy research and development funding are helpful steps. The key to fostering accelerated renewable energy development, however, lies most in the hands of state regulators. Federal support, assistance, and encouragement that help state regulators will provide the surest, fastest way to expedite development of these important resources.

\section{Conclusion}

Renewable energy technologies have tremendous potential to supply energy cost-effectively and also respond to serious environmental concerns. External costs of fossil energy production and lise are real costs that consumers must pay at some point. Clearly, renewable energy technologies can lower these real costs while supplying the services energy provides.

To apply the experience gained and lessons learned through this assessment of renewable energy, the Task Force has developed a renewable energy agenda for NARUC to consider. It consists of five suggested programs or projects and several associated activities. These are:

\#1 A Renewable Energy Information Program Tailored for Utility Regulators

\#2 Preparation of In-Depth Case Studies on Regulatory Practices to Pinpoint Biases Against Renewable Energy Resources and Demonstrate Successful Alternative Approaches 
\#3 An Assessment of the Potential of Dispersed Renewable Energy Technologies and Regulatory Barriers Impeding their Development

\#4 Implementation of a "Next Renewable Energy States" Program

\#5 Review of the Impact of Environmental and Tax Policies on Integrated Resource Planning and Deployment of Renewable Energy Resources

We also recommended associated initiatives that pertain to treatment of renewable energy in the National Energy Strategy that will be forthcoming and organization of experts workshops on topics related to the suggested renewable energy agenda. Section III describes the agenda and associated recommendations in detail. 


\title{
RENEWABLE ENERGY AND UTILITY REGULATION
}

\author{
A REPORT PREPARED FOR THE \\ NARUC TASK FORCE ON RENEWABLE ENERGY
}

\section{BACKGROUND}

With financial support from the U.S. Department of Energy, the National Association of Regulatory Utility Commissioners (NARUC) has undertaken an assessment of renewable energy. The technologies considered were:

Solar energy*

Wind energy

Geothermal energy

Hydroelectricity

Biofuels, including waste-to-energy

* Includes photovoltaic and solar thermal

Ocean energy systems, which have only limited, experimental operational data in the United States, were not reviewed.

NARUC and DOE agreed that the project framework would be based on the following six questions:

1. What is the current state-of-the-art with respect to renewable energy technologies, including deployment and operating experience? Which technologies hold the most promise for the immediate time horizon?

2. What is the potential for further development of renewable energy -- e.g. which states have potential which is not currently being exploited?

3. What factors have contributed most to date toward the successful implementation of renewable energy technologies?

4. What factors have hindered development of renewable energy?

5. What public policy lessons can be learned from the experiences to date with renewables?

6. What studies, reports, models, etc. are needed to provide information on renewable energy to the regulatory community? 
It was decided early in the project to focus on two areas:

- How renewable energy fares in the current economic and regulatory environment.

- How can change in utility regulation encourage more reliance on renewable energy.

In order to address the six questions and the focus, the project work plan consisted of three elements:

A. Compile information on promising technologies and factors that affect market development for these technologies prior to holding a seminar.

B. Use a seminar/workshop to draw policy conclusions and generate recommendations for NARUC on renewable energy and utility regulation.

C. Review the seminar proceedings and extract a concise report on key concepts and findings.

Attendees at the seminar included utility regulators, utilities, and renewable energy companies. These participants provided information prior to the seminar, and then reacted to key concepts and findings drawn from their input.

The final project report was prepared to furnish insights and conclusions drawn from consideration of the six areas of inquiry agreed upon between NARUC and the Department of Energy. The body of the report proceeds as follows:

Section I: Status of renewable energy technologies

Section II: Lessons from past development of renewable energy

Section III: A recommended renewable energy agenda for NARUC

The project also created additional material used to poll the workshop participants and brief them on the potential of renewable energy resources. In addition, the project contractors received documents from many of the participants on state regulatory actions that have affected deployment of renewable energy resources, and on utility and industry perspectives on the status of renewable energy technologies and the issues surrounding their deployment. Material to conduct the workshop included a set of twenty-eight propositions about utility regulation and renewable energy. These were employed to stimulate discussion. To not overburden the final report, however, these materials were excluded. Those interested in fuller documentation can contact NARUC or the project consultants for access to this additional documentation. 


\section{SECTION I: RENEWABLE ENERGY CONTRIBUTIONS, COSTS AND POTENTIAL}

This section provides an overview of the current status of renewable energy technologies in energy markets and their future potential. Renewable energy systems may be classified into three types:

A. Utility scale electric power technologies (centralized)

B. Dispersed electric and thermal technologies

C. Fuel production technologies

Utility scale power technologies and dispersed systems are the technologies covered in this assessment. The limited resources for the assessment makes it impossible to provided detailed performance data for all types of renewable energy systems in all climate zones. Instead, information from general sources describe how renewable energy systems are performing and cost ranges indicate the relative competitiveness of these technologies.

\section{CURRENT CONTRIBUTION}

Renewable energy technologies contribute power to electric utility grids in baseload, intermediate and peaking facilities powered by hydro, biomass, wind, geothermal and solar energy resources. Dispersed solar, wind, geothermal and biomass energy technologies are also offsetting demand for electricity by providing energy directly to end-users. Dispersed renewable energy systems include wood burners, solar heating and photovoltaic systems, ground coupled heat pumps and individual wind turbines. The contribution of dispersed and centralized renewable energy systems to national energy supply is substantial.

To support preparation of a new National Energy Strategy, several national laboratories and the Solar Energy Research Institute conducted a renewable energy assessment for the Department of Energy. Released in early 1990, Potential of Renewable Energy: An Interlaboratory White Paper, reports that in 1988, renewable sources of energy contributed 6.7 quadrillion British thermal units $\left(10^{15} \mathrm{Btu}\right)$ to the total national energy consumption of 82 quadrillion Btu (shortened to quad). This amounted to 8.2 percent of national energy supply.

From the interlaboratory white paper, Table I-1 lists 1988 contributions of renewable energy to national energy supply by technology in quadrillion Btu.

Hydroelectric power, geothermal electric power, and biomass energy for electricity and thermal applications account for 6.6 quads of the energy contribution. These technologies

* . are well proven, and have operating characteristics that make them similar to fossil energy power plants that utilities and other energy users know well. According to the laboratory analysis, the remaining technologies, solar, wind, ocean energy and geothermal heating, provide about 0.1 quad. Two of them, solar and wind energy, are most often characterized as an intermittent energy resource systems because solar radiation and wind availability 
varies diurnally and seasonally. The others are baseload or intermediate load technologies.

TABLE I-1

\begin{tabular}{lc}
\multicolumn{2}{c}{ RENEWABLE ENERGY CONTRIBUTION TO U.S. } \\
ENERGY SUPPLY IN 1988 ACCORDING TO DOE (Quads) \\
HYDROPOWER & 3.1 quads \\
GEOTHERMAL ELECTRIC & 0.2 \\
GEOTHERMAL HEAT & $<0.1$ \\
SOLAR HEAT-BUILDINGS & $<0.1$ \\
SOLAR HEAT-INDUSTRIAL & $<0.1$ \\
SOLAR THERMAL ELECTRIC & $<0.1$ \\
PHOTOVOLTAICS & $<0.1$ \\
WIND POWER & $<0.1$ \\
OCEAN THERMAL & 0.0 \\
BIOMASS-ELECTRIC & 0.5 \\
BIOMASS-BUILDING & 1.0 \\
BIOMASS-INDUSTRIAL & 1.8 \\
BIOMASS-LIQUID FUELS & $\leq 0.1$
\end{tabular}

TOTAL

6.7 Quads

To summarize, biomass and hydroelectric systems are the renewable energy technologies contributing the most to U.S. energy supply at the present time. Except for ocean energy, the contribution from other renewable energy technologies is now measurable, which represents a major development of the last decade.

Table I-1 presents the gross energy output of renewable energy systems. Another measure is the total installed capacity of renewable energy electric power facilities. In 1989, a Public Citizen study of this capacity reported that in 1980, excluding hydroelectric systems, 1,109 megawatts of renewable energy electric capacity existed in the United States, and that by 1988 , this figure had grown to 9,500 megawatts. ${ }^{1}$

Counting hydroelectric systems, Public Citizen reported that total renewable energy electric

${ }^{1}$ Rader, Nancy. Power Surge; Public Citizen; Washington, DC 1989. Page II-1. 
power capacity had grown to 97,443 megawatts by the end of $1988 .^{2}$ Public Citizen notes that this figure matches total nuclear power capacity, and that 90 percent of the non-hydroelectric renewable energy capacity was built after 1980, following passage of the Public Utility Regulatory Policies Act of 1978.

Another study published in 1989 confirms the fast rate of growth of renewable energy systems in the electric power sector. The Investor Responsibility Research Center, located in Washington, D.C., produced a study titled Power Plays, that tallies the renewable energy capacity of 108 independent energy producers. Table I-2 summarizes the growth in capacity for these companies between 1984 and 1988.

TABLE I-2

INSTALLED CAPACITY OF IRRC SURVEY SAMPLE AND CONSTRUCTION PLANS (Electric megawatts of capacity)

$\begin{array}{lcccc} & \begin{array}{l}\text { Installed } \\ \text { Capacity } \\ \text { 1984 }\end{array} & \begin{array}{l}\text { Installed } \\ \text { Capacity } \\ 1988\end{array} & \begin{array}{l}\text { Firm Plans } \\ \text { for } \\ \text { New Capacity }\end{array} & \begin{array}{l}\text { Projected } \\ \text { Capacity } \\ 1995\end{array} \\ \text { Biomass } & 153.3 & 1,371.7 & 2,570.5 & 4,432.4 \\ \text { Geothermal } & 1,372.2 & 2,306.2 & 426.6 & 3,320.2 \\ \text { Wind } & 599.7 & 799.2 & 360.0 & 1,197.9 \\ \text { Hydro } & 83.9 & 450.2 & 721.2 & 1,208.3 \\ \text { Photovoltaics } & 7.5 & 7.5 & 155.2 & 167.7 \\ \text { Solar Thermal } & 19.6 & 199.6 & 400.0 & 679.6 \\ \text { Ocean } & 0.0 & 0.0 & 0.0 & 106.0 \\ \text { Unidentified } & 0.0 & 0.0 & -0.0 & 102.4 \\ & & & & \end{array}$

${ }^{2}$ This figure includes approximately 17,000 megawatts of pumped hydroelectric capacity, a peak power energy storage/delivery system that actually absorbs a net amount of energy. 
TABLE I-3

\title{
1988 INSTALLED RENEWABLE ENERGY ELECTRIC CAPACITY BY SOURCE ACCORDING TO IRRC
}

$\begin{array}{lc}\text { Geothermal } & 45 \% \\ \text { Biomass } & 27 \% \\ \text { Wind } & 16 \% \\ \text { Hydro } & 9 \% \\ \text { Solar Thermal } & 4 \%\end{array}$

TABLE I-4

\begin{abstract}
FIRMLY PLANNED RENEWABLE ENERGY ELECTRIC CAPACITY ADDITIONS BY SOURCE ACCORDING TO IRRC
\end{abstract}

$\begin{array}{lr}\text { Biomass } & 52 \% \\ \text { Hydro } & 15 \% \\ \text { Geothermal } & 15 \% \\ \text { Solar Thermal } & 8 \% \\ \text { Wind } & 7 \% \\ \text { Photovoltaics } & 3 \%\end{array}$

From the IRRC data, Table I-3 reveals that in 1988, geothermal energy capacity was the dominant renewable energy electric power resource among the 108 companies surveyed. Data from the IRIRC survey on the firm plans of the 108 companies to add new power plants reveals (see Table I-4) that for new capacity additions, biomass technologies would dominate market growth instead of geothermal energy.

The survey data for 108 independent energy producers and renewable companies revealed that their renewable energy electric capacity grew 230 percent between 1984 and 1988, and that firm plans for new additions would expand 1988 capacity by another 90 percent in the next few years. Looking ahead, for this group of companies, installations of biomass energy systems will expand much faster, and solar thermal and photovoltaic installations will rise significantly from a small base. As a result, wind and geothermal installations would actually fall as a percent of new supply additions. While proven technologies continue to dominate market expansion, some newer technologies--solar thermal, photovoltaics--are gaining. 


\section{PERFORMANCE OF DISPERSED RENEWABLE ENERGY SYSTEMS}

Reports on projections of renewable energy resource potential often ignore smaller scale building or remote site technologies that provide heat or electricity independently from the existing energy delivery system. The potential for these systems to contribute more energy is relatively high. DOE has reported that in 1986, the building sector in the United States consumed 28.6 quads of energy, roughly 37 percent of national energy supply. A residential or commercial building can be designed and equipped with renewable energy systems that eliminate conventional energy consumption completely, and a few buildings like this exist. Economics generally dictate, however, that on-site renewable energy systems for buildings satisfy anywhere from 10 to 80 percent of the energy loads. The ratio will depend on the site, the application, cost of capital, and belief of the system purchaser about future conventional fuel prices.

Currently, the largest number of small renewable energy installations are wood heating and solar thermal heating systems. In 1980, four percent of residences relied on wood energy as the primary fuel for heating. Data for 1983 estimate that wood provided 925 trillion Btu of energy for these systems. ${ }^{3}$ Four percent of the housing stock in 1990 would amount to 3.6 million installations.

Active solar energy installations for space heating, water heating and pool heating in the residential and commercial sector expanded rapidly in the early 1980s when federal and state investment tax incentives supported market development. From 1.2 to 1.5 million such systems exist, representing an inventory of solar thermal collectors of 170 million square feet.

Today, small-scale solar heating technologies deliver thermal energy from between $\$ 14$ and $\$ 30$ per million Btu. (The equivalent of 5 to 10 cents per kilowatt hour). Analysis for the International Energy Agency has predicted that large array solar systems can deliver thermal energy for between two and five cents per kilowatt hour over their life. ${ }^{4}$ Actual cost depends on a wide range of factors, including the availability of solar energy, the characteristics of the load and time of day energy is used. In general, such systems are competitive in areas where high cost electricity satisfies thermal energy loads.

From 300,000 to 400,000 buildings in the United States have passive solar designs which typically reduce energy consumption for heating and cooling by 40 to 60 percent compared to conventional structures. Constructing a thorough solar design generally adds between 5 and 15 percent to the cost of a building. However, some simple solar design features (e.g.

${ }^{3}$ Energy Information Administration, U.S. Department of Energy. Estimates of U.S. Wood Energy Consumption 1980-1983. Page 27.

${ }^{4}$ Private Communication. CBY Associates. Washington, DC. 
moving windows to south facades) add no costs. The energy delivered in passive solar buildings is very competitively priced compared to any other energy source.

Photovoltaic technologies that produce electricity in small scale systems have already created niche, high value markets where they are selected for convenience and reliability. These technologies also have potential to expand in the residential and commercial building sector as a micro-baseload system or a peak shaving system. In remote locations, it can be less costly to a utility to install a complete photovoltaic system with battery storage to serve a residence than to run a power line extension from the grid. Photovoltaic systems that deliver electricity for a levelized cost of $\$ 0.30$ to $\$ 0.50$ may also be competitive in areas where utilities experience high short-term demand for electricity to meet summertime peaks. Utilities may find that many small photovoltaic systems strategically located within a grid may already be more cost effective than installation of a seldom used standby peak generator. Small sized solar thermal parabolic dishes with Stirling engine generators from 4 to 25 kilowatts in size would also serve this market niche.

Sales of small individual wind turbines $(1-5 \mathrm{kWe})$ in the United States peaked at 800 to 1000 units per year during the period when federal tax credits were available to cover 40 percent of the first $\$ 10,000$ spent on the system. ${ }^{5}$ When tax credits for wind energy expired in 1985, the market for such individual systems for electric power production collapsed to a low level. The wind industry is now dominated by firms that build and install large wind turbines in multi-turbine wind plants. Still, small individual wind turbines in high wind locations are capable of delivering electricity for less than 10 cents per kilowatt hour over their life.

This brief summary of distributed renewable energy technologies could also include ground-coupled heat pumps. Proponents of this heating approach label it geothermal energy, and it is estimated that 75,000 such systems now exist, and the market is expanding at a rate near 10 percent per year.

There has been a tendency to discount the value of small scale renewable energy systems in energy policy planning and focus most attention on large-scale utility systems. This happens in part because of the heavy emphasis the U.S. Department of Energy places on large-scale electric technologies rather than renewable energy technologies. In addition, there appears to be a reluctance on the part of some policy makers to embrace renewable energy technologies because of over optimistic forecasts of their near-term potential made in the 1970s. In reality, these resources already provide a substantial amount of energy. Furthermore, the extensive available resource bases, declining costs for existing and newer technologies, and their increasing efficiency all mean the potential of dispersed renewable energy systems is great.

${ }^{5}$ C. LaPorta and K. Porter. Unpublished R \& C Enterprises study for American Wind Energy Association, 1984. 


\section{TABLE I-5}

\section{COMMERCIALLY AVAILABLE ELECTRICITY GENERATION \\ TECHNOLOGIES WITH UTILITY OWNERSHIP \\ (Constant 1987 levelized \$ In service date 1995)}

Base Load Technologies (50 to 75 Percent Capacity Factors)

Geothermal

Steam

Liquid (Flashed Steam)

Liquid (Binary Cycle)

Liquid (Rotary Separated

Turbine)

Conventional Hydroelectric

Biomass

Direct Combustion

Gasifier With Engine

Anaerobic Digester w/Engine
Cents/kwh

$4.7-6.2$

$4.3-6.8$

$4.4-6.3$

$3.3-15.8$

$5.2-18.9$

$4.2-7.9$

$3.6-6.5$

$3.9-8.7$

Intermittent Technologies (Capacity Factor Varies by Resource)

Wind
Utility Scale
$4.7-7.2$
Distributed Use Systems
$6.1-15.4$

Solar Thermal Electric

Parabolic Trough Hybrid (1990) 6.0 - 7.8

Parabolic Trough Hybrid (1995) $4.7-6.0$

Pumped Hydro Storage System

$9.3-14.3$

Selected Conventional Technologies (60-75\% Capacity Factor)

Natural Gas Utility Boiler

Natural Gas Combined Cycle

Coal Boiler

Coal Atmospheric Fluid Bed

Coal Int. Gasif. Combined Cycle

Light Water Reactor-Pressurized

Light Water Reactor-Boiler
$4.9-6.1$

$4.4-5.0$

$4.5-7.0$

$6.0-9.5$

$5.3-10.4$

$5.3-9.3$

$5.7-9.7$ 


\section{COSTS OF RENEWABLE ENERGY TECHNOLOGIES}

The cost of energy from renewable energy technologies depends on site- specific factors as well as capital and operation and maintenance costs, and costs of land and capital. Tables I-5 through I-7 present the energy cost estimates developed for renewable energy technologies in California by the California Energy Commission in a study completed in Spring 1990. The California Energy Technology Status Report cost figures are specific to California and costs in other parts of the U.S. could be higher or lower. Nevertheless, these costs provide insights into the significant gains renewable energy technologies have made.

\section{TABLE I-6}

\section{NOT YET COMMERCIALLY AVAILABLE ELECTRICITY GENERATION TECHNOLOGIES WITH UTILITY OWNERSHIP}

Base Load (60 - $75 \%$ Capacity Factor)

Geothermal

Liquid (Bladeless Turbine)

Liquid (Helical Screw Expander)

Solar Thermal

Salt Pond (1990).

Salt Pond (1995)

Ocean Energy Conversion

Thermal (current)

Thermal (1998)
Cents/KwH

$3.4-8.2$

$5.1-7.1$

$5.4-6.9$

$3.8-5.2$

$18.8-24.5$

$6.9-7.9$

Intermittent Technologies (Capacity Factor Varies by Resource)

Solar Thermal Electric

Central Receiver (2000)

Central Receiver (2004)

Central Parabolic Dish (1995)

Central Parabolic Dish (2004)

Photovoltaics

Central Station Crystal Silicon (1987)

Central Station Crystal Silicon (1997)

Central Station Crystal Silicon (2007)

Distributed Use Systems

Ocean Energy Conversion

Tidal

Wave

$$
\begin{array}{r}
5.6-7.0 \\
3.6-4.8 \\
13.7-17.1 \\
7.0-8.6 \\
\\
25.3-34.6 \\
9.3-12.7 \\
6.2-8.4 \\
44.5-55.5 \\
\\
8.6-15.4 \\
100.2-124.9
\end{array}
$$


The California Energy Commission also prepared levelized cost estimates for these technologies if they were owned by either a government utility or by an independent energy producer. In general, government utility ownership tends to lower the levelized delivered energy costs, while independent energy producer ownership makes them somewhat higher.

The Energy Cornmission also performed similar analysis for commercially available end-use technologies. The costs are expressed in cents per kilowatt hour or dollars per million Btu, again, in constant 1987 dollars.

\section{TABLE I-7 \\ COMMERCIALLY AVAILABLE END-USE TECHNOLOGIES}

Residential (Electricity)

Active Solar Water Heater (vs. Electric) $\quad 4.8-12.6$ cents $/ \mathrm{kwh}$

Passive Solar Water Heater (vs. Electric) $\quad 4.6-15.9$ cents/kwh

Residential (Thermal) Multiple Use Technologies (in dollars per million Btu)

Active Solar Water Heating $\quad 10.01-15.04 \$ /$ MBtu

Passive Solar Water Heating $\quad 4.73-9.85 \$ /$ MBtu

Passive Solar Space Conditioning
Inland Valley
$0.00-3.21 \$ / \mathrm{MBtu}$
South Coast
$0.00-5.53 \$ / \mathrm{MBtu}$

Commercial

Active Solar Industrial Process Heat $\quad 2.77-9.88 \$ /$ MBtu

The California figures cited above indicate the range of costs for renewable energy technologies in a state that has gained significant levels of experience with these technologies. The figures indicate how close different renewable energy technologies are to a competitive position. 


\section{RESOURCE POTENTIAL}

Every state has a renewable energy resource base to exploit. For example, across the nation available solar energy on a ground-mounted surface ranges from 1000 to 2800 kilowatt hours per square meter per year. Daily averages of annual direct radiation (sunlight on an object always pointed directly at the sun, for example, a tracking collector) per square meter for different regions is:
Northeast
$2.5-3.5 \mathrm{kWh} / \mathrm{sq}$. meter/day
Southeast
$3.0-4.1 \mathrm{kWh} / \mathrm{sq}$. meter/day
Southwest
$6.6-7.5 \mathrm{kWh} / \mathrm{sq}$. meter/day
West
$4.9-7.1 \mathrm{kWh} / \mathrm{sq}$. meter/day
Plains
$4.2-6.0 \mathrm{kWh} / \mathrm{sq}$. meter/day

Another perspective on the resource availability is to consider the amount of solar radiation available on a building surface as a ratio of its heat requirement. The supply far exceeds demand. Thus, the following ratios apply at different latitudes:

$\begin{array}{ll}\text { Northern Most Latitudes } & 4: 1 \text { Solar Energy to Heat Required } \\ \text { Middle Latitudes } & 5: 1 \text { to } 10: 1 \\ \text { Southern Latitudes } & 20: 1 \text { to } 50: 1\end{array}$

How much renewable energy displacement of fossil fuels is possible? World-wide, renewable energy accounts for approximately 20 percent of total primary energy supply. About seventy-five percent of the contribution comes from hydro power. A large share of the remainder is biomass energy.

In every country, however, the combined solar, biomass, geothermal, hydroelectric and wind energy potential overshadow reserves of petroleum, natural gas, coal and uranium.

For the United States, one of the richest countries in terms of fossil energy reserves, renewable energy resources actually dominate the total energy resource base projected into the next century. A Meridian Corporation study for the U.S. Department of Energy calculated an estimate of accessible energy reserves using standard government energy accounting procedures. "Accessible" means a limit on the resources to include only those deliverable with current technology or with technologies to be available in the very near term.

The calculations of accessible resources presented in Table I-8 eliminated land areas already occupied by urban and suburban development, or for which other competing uses would preclude renewable energy conversion. Furthermore, laws that restrict energy operations in park lands are taken into account and hydroelectric potential is severely curtailed by assuming that objections to it by groups concerned about dam impacts govern policy on expansion of hydro at new sites. The result shows that energy potential from photoconversion (solar and biomass energy systems) is very high, far exceeding all other future 
U.S. energy sources. Meridian's assumed limitations on hydroelectricity development may cause it to be underestimated. However, it should be noted that certain interest groups are exerting pressures that could even result in existing hydroelectric facilities being closed down.

\begin{tabular}{lc}
\multicolumn{1}{c}{ Energy Source } & BBOE \\
Photo-conversion (Solar \& Biomass *) & 101,153 \\
Coal & 6,577 \\
Geothermal & 3,928 \\
Shale Oil & 2,018 \\
Wind & 870 \\
Petroleum & 190 \\
Natural Gas & 153 \\
Uranium & 126 \\
Peat & 61 \\
Hydropower & 27
\end{tabular}

TABLE I-8

\section{U.S. ACCESSIBLE RESOURCES OF ENERGY} (Billion Barrels of Oil Equivalent)

* Includes waste to energy projects

To summarize, available renewable energy resources far exceed U.S. energy demand and will sustain a rapid transition away from conventional energy resources as these reserves dwindle and become more expensive to extract.

The cost information reveals that renewable energy technologies deliver energy at levelized costs that range from a low between 3 and 7 cents per kilowatt for several technologies to highs between 40 and 55 cents for others farther from commercial readiness. These cost figures include both electricity producing technologies in power stations and small dispersed renewable energy systems.

Predicting how much renewable energy capacity will expand over the next decades is very difficult. Some have estimated that the current contribution of about 8 percent could double in the next decade if incentives and favorable policies are enacted. The study of such scenarios has been quite limited in recent years, and no reliable estimates are available. The potential exists for states to make such determinations for their own economies, but only a few are conducting such assessments.

Certain renewable energy technologies have gained solid market/investor confidence and will expand in the economy as the economy requires more energy. These include:

Hydroelectricity

Hydrothermal geothermal
Waste-to-Energy

Small remote photovoltaic systems 


\section{Direct combustion biomass}

A longer list of additional renewable energy technologies have proven technical capability and are gaining market acceptance. These technologies will expand more quickly in energy markets as states decide to encourage expansion of cleaner sources of energy supply:

Multiple wind turbine energy plants

Individual wind turbines

Moderate temperature geothermal

Parabolic trough, gas hybrid solar thermal

Remote photovoltaic systems

Passive solar building design

Active building and industrial process solar heating

The following examines where renewable energy technologies are already contributing substantially to energy supplies, and where potential for faster expansion is not being realized.

\section{STATE-BY-STATE ASSESSMENT OF RENEWABLE ENERGY USE}

In June 1990, Public Citizen released the results of a survey to determine renewable energy contributions to energy supply in each state. The survey includes energy output as electricity, heat, and liquid fuels. The data are based on information states provided and estimates made by the staff of Public Citizen and is almost the only report on this topic to have emerged in several years.

Counting hydroelectricity, Public Citizen identified eight states that rely on renewable energy for more than 20 percent of their energy supplies. Washington is the leader, with over half of its energy coming from renewable energy resources. Besides these eight, another nine sitates rely on renewable energy for between 10 and 20 percent of their supply. These states are listed in Table I-9.

\section{TABLE I-9}

STATES REALIZING RENEWABLE ENERGY POTENTIAL (Percent of Total Energy from Renewables for All Applications) (Includes Hydro)

$\begin{array}{lll}\text { Washington } & 53.54 \% & \text { States between } 10 \& 20 \text { percent } \\ \text { Oregon } & 47.46 & \\ \text { Idaho } & 46.49 & \text { Alabama, Arkansas, Mississippi } \\ \text { South Dak. } & 29.42 & \text { Georgia, California, Nortl Carolina } \\ \text { Montana } & 28.97 & \text { Tennessee, South Carolina, New York } \\ \text { Maine } & 27.00 & \end{array}$




\section{Vermont 22.64 \\ New Hamp. 20.21}

Eliminating energy contributed by hydroelectric systems presents another perspective on renewable energy contributions to the various states. 'Table I-10 lists eight states that rely on non-hydro renewable resources for 12 to 18 percent of their energy supplies, and 13 more states that rely on renewables for between five and 10 percent of their energy. A primary renewable energy supply resource in the eight leading states is biomass energy.

TABLE I-10

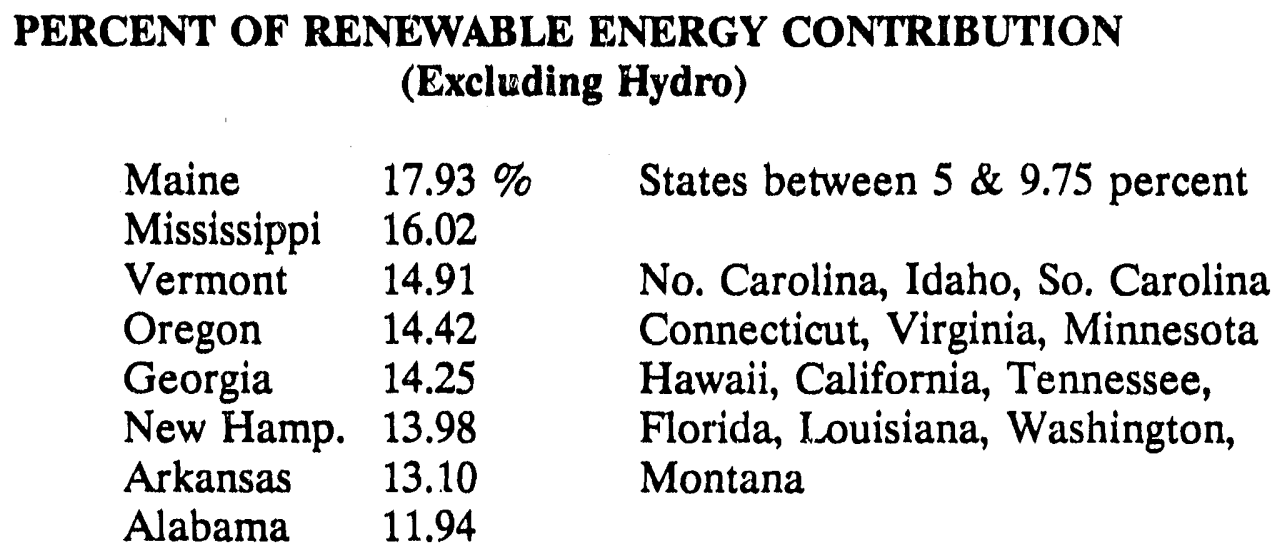

TABLE I-11

\section{STATES WITH LESS THAN 10 MEGAWATTS OF RENEWARLE ENERGY ELECTRIC CAPACITY [EXCLUDING HYDROPOWER]}

$\begin{array}{llll}\text { West Virginia } & \text { South Dakota } & \text { Nebraska Indiana } \\ \text { Missouri } & \text { Kansas } & \text { New Mexico Iowa } \\ \text { Alaska } & \text { Kentucky } & \text { Colorado } & \text { Wyoming } \\ \text { Rhode Island } & \text { North Dakota } & & \end{array}$

According to the Public Citizen data in Power of the States, fourteen states, again excluding hydropower, have less than 10 megawatts of renewable energy electric capacity. They are listed in Table I-11.

Table I-12 combines this list of states and with those that receive less than two percent of their energy from renewable sources of supply. This roster could be identified as states that 
are failing to realize as much potential from renewable energy resources as they could.

TABLE I-12

STATES THAT COULD EXPAND RENEWABLE ENERGY POTENTIAL

$\begin{array}{llll}\text { Alaska } & \text { Arizona } & \text { Colorado } & \text { Indiana } \\ \text { Iowa } & \text { Kansas } & \text { Kentucky } & \text { Missouri } \\ \text { New Jersey } & \text { New Mexico } & \text { N. Dakota } & \text { Oklahoma } \\ \text { Rhode Is. } & \text { S. Dakota } & \text { Texas } & \text { Utah } \\ \text { West Virginia } & \text { Wyoming } & & \end{array}$

Studies should be conducted in each state to determine how much renewable energy resource capacity exists and what measures could be employed to realize this potential. An imprecise attempt to pinpoint unrealized potential to capture renewable energy resources is made in this assessment just to begin such a process. The crude methodology used here is to match general data on renewable resource availability against states that have less than 10 megawatts of commercial renewable energy capacity in place. (Those listed in Table I-11).

\section{* Solar Electric Potential}

States with locations where average annual direct solar radiation exceeds $6 \mathrm{kwh} / \mathrm{square}$ meter per day, but with less than 10 megawatts of commercially installed solar electric capacity.

$\begin{array}{lll}\text { Colorado } & \text { Texas } & \text { New Mexico } \\ \text { Arizona } & \text { Nevada } & \text { Kansas } \\ \text { Utah } & \text { Wyoming } & \text { Oklahoma }\end{array}$

** Wind Energy Potential

States that have regions where annual wind speed averages more than $13.4 \mathrm{mph}$, but which have less than 20 megawatts of installed wind energy capacity.

$\begin{array}{lllll}\text { Alaska } & \text { Nevada } & \text { Idaho } & \text { Utah } & \text { Wyoming } \\ \text { Colorado } & \text { New Mexico Oklahoma } & \text { Texas } & \text { New Hampshire } \\ \text { Kansas } & \text { Tennessee } & \text { New York } & \text { Maine } & \text { No. Carolina }\end{array}$

** Geothermal Energy Potential

States with geothermal resources with temperatures above 90 degrees Celsius. 


\begin{tabular}{|c|c|c|c|c|}
\hline $\begin{array}{l}\text { California } \\
\text { Arizona }\end{array}$ & $\begin{array}{l}\text { Washington } \\
\text { New Mexico }\end{array}$ & $\begin{array}{l}\text { Oregon } \\
\text { Colorado }\end{array}$ & $\begin{array}{l}\text { Nevada } \\
\text { Wyoming }\end{array}$ & $\begin{array}{l}\text { Idaho } \\
\text { Montana }\end{array}$ \\
\hline Alaska & Hawaii & Utah & & \\
\hline
\end{tabular}

States with high temperature geothermal resources but less than 50 megawatts of commercially installed electric capacity.

$\begin{array}{llll}\text { Washington } & \text { Oregon } & \text { Idaho Arizona } & \text { New Mexico Colorado } \\ \text { Wyoming } & \text { Montana } & \text { Utah Alaska } & \text { Hawaii }\end{array}$

** Biomass Energy Potential ${ }^{6}$

States with less than 10 megawatts of installed renewable energy capacity, excluding hydropower, with forest-land exceeding 22 percent of total land area:

Alaska Colorado Kentucky Missouri

New Mexico Rhode Island West Virginia

Indiana with 17 percent forest-land, and Wyoming with 16 percent forest-land also have less than 10 megawatts of non-hydro renewable energy capacity.

Another potential source of biomass energy is herbaceous crops. States with cropland exceeding 21 percent of total land area that could grow such energy crops but having less than 10 megawatts of installed renewable energy capacity, excluding hydropower:

$\begin{array}{lllll}\text { Indiana } & \text { Iowa } & \text { Kansas } & \text { Kentucky } & \text { Missouri } \\ \text { Nebraska } & \text { No. Dakota } & \text { So. Dakota } & & \end{array}$

Note: These lists overlook other biomass resource potentials, such as waste-to-energy or agricultural residues.

** Hydropower Potential

Geographic Regions with Undeveloped Hydropower Resources that Exceed the Current Amount of Developed Hydropower $\begin{array}{llll}\text { West North Central } & \text { West South Central } & \text { Mountain } & \text { New England } \\ \text { East North Central } & \text { South Atlantic } & \text { Middle Atlantic } & \end{array}$

${ }^{6}$ Office of Technology Assessment. Energy form Biological Processes. Vol. II. U.S. Congress. July, 1980. 
This very generalized approach suggests that a number of states have the resource base to contribute more renewable energy to their economies, but have not witnessed very much renewable energy development. A more comprehensive review on a state-by"state basis is required to assess actual renewable resource potential under current conditions and with changes in state regulatory and legislative policy. The Task Force assessment revealed that very few states have developed such projections. The data provided here represent a first approximation that requires substantial expansion. Such analysis would figure in the Next Renewable Energy States program recommended to NARUC in Section III. 


\section{SECTION II}

\section{FACTORS AFFECTING DEVELOPMENT OF RENEWABLE ENERGY RESOURCES}

Adding new capacity to a utility system is a complex process. Selling dispersed renewable energy systems to consumers unfamiliar with or wary of new technologies can also require strenuous effort, and nearly anyone in the renewable energy business relates how difficult it has been to build their business while their technologies were proving themselves, even when policies were in place that promoted or provided incentives for renewable energy systems. Nonetheless, a remarkable exnansion of renewable energy has occurred in the last decade, positioning many renewable energy technologies for rapid expansion in the decade ahead.

This section describes key factors affecting successful deployment of renewable energy resources and summarizes several policy conclusions that emerged from the Task Force assessment. It provides the basis for the renewable energy agenda for the National Association of Regulatory Utility Commissioners proposed in Section III.

\section{SUCCESS FACTORS}

An examination of events in states where renewable energy market penetration is substantial plus consideration of the insights and experience furnished by the Task Force participants have helped identify several factors essential for successful deployment of renewable energy technologies in the market. The narrative which follows draws on experience in California and in Maine to pinpoint the factors which enhance renewable energy performance in energy markets.

California is a leading state in renewable energy utilization. In the 1970s, it acted quickly to develop a comprehensive energy policy strategy. A central component of this strategy was California's implementation of the Public Utility Regulatory Policies Act of 1978 (PURPA). The results of these policies, and adjustments to them made in the 1980s, led directly to substantial additions of renewable energy capacity. Figure II-1 shows the total of rated capacity for each renewable resource and its share of the market for qualifying facilities in California in 1990.

From 1979 to 1989, private power generation in California expanded from five megawatts to more than 8000 megawatts of installed capacity. Sixty percent of the new capacity on line 
in 1989 was renewable-energy based, forty percent was gas-fired cogeneration systems. ${ }^{7}$ The firm capacity facilities among these private power plants are operating with capacity factors of 90 to 95 percent. The best wind energy plants are showing availabilities in excess of 95 percent. The average price paid for energy from these projects is 5.5 cents per kilowatt hour. Compared to the Diablo Canyon Nuclear Generating Station, this capacity was added in half the time at 60 percent of the cost. ${ }^{8}$

FIGURE II-1

\section{CALIFORNIA ALTERNATIVE ENERGY PROJECTS TECHNOLOGICAL MIX AND CAPACITY \\ (As of June 1990)}

$\begin{array}{lcccc}\begin{array}{l}\text { Technology } \\ \cdot\end{array} & \begin{array}{l}\text { On Line } \\ \text { (MWe) }\end{array} & \begin{array}{l}\text { \% of On-Line } \\ \text { Systems }\end{array} & \begin{array}{c}\text { Non-Generating } \\ \text { Under Contract * * }\end{array} & \begin{array}{l}\text { Discussion } \\ (\mathrm{MWe})\end{array} \\ \text { Cogen } & 5,098 & 60 & 2,129 & 260 \\ \text { Biomass } & 539 & 6 & 384 & 19 \\ \text { Solar } & 299 & 4 & 389 & 10 \\ \text { Geothermal } & 767 & 9 & 4.9 & 15 \\ \text { Wind } & 1,480 & 17 & 1,826 & 0 \\ \text { Hydro } & 341 & 4 & 209 & 129\end{array}$

Source: California Public Utility Commission quarterly utility reports. Note: The California PUC does not include utility-owned projects in its quarterly reports on alternative energy.

* Capacity in projects with signed contracts but which are not yet on line.

** Capacity of known projects still in contract negotiation or feasibility stages.

${ }^{7}$ J. Hamrin Associates. Compiled from Cogeneration/Small Projects Quarterly Reports filed by California utility companies.

${ }^{8} \mathrm{~J}$. Hamrin Associates Brief. 
According to Figure II-1, 1990 renewable energy capacity on line in California in independent energy projects totaled 3,426 megawatts. The distribution among technologies was as follows:

$\begin{array}{ll}\text { Biomass } & 16 \text { percent } \\ \text { Wind } & 43 \text { percent } \\ \text { Geothermal } & 22 \text { percent } \\ \text { Small Hydro } & 10 \text { percent } \\ \text { Solar } & 9 \text { percent }\end{array}$

California's willingness to implement PURPA vigorously was a central component of a clearly articulated state government policy that called for change in the energy sector. When the 1980s began, California still depended on petroleum for 58 percent of its total energy supply and natural gas for 32 percent. Forty percent of its oil came from foreign sources. Because oil or gas fired power plants generated more than fifty percent of the electric power in California, the state energy policy had to include utility regulation. The energy shocks of the 1970s established a firm government commitment to diversification and a desire for technologies that would be lower in cost than $\$ 30$ per barrel oil.

The economic and political environment in California included other factors that amplified the favorable effect of the regulatory policy changes. In particular, in the late 1970s and early 1980s, utilities were under a financial strain because of their dependence on oil and gas. New capacity was expensive in a high inflation period, electric rates were rising quickly, and consumers were stridently opposed to conventional utility solutions. The state government had also imposed tight regulations to safeguard against nuclear power accidents and restrict air pollution from burning fossil fuels. Coal was only providing about 6 percent of the electricity produced in California and most of this was burned outside the state. At the same time, California's population continued to grow and its economy expand.

California enacted a wide range of energy policy initiatives that included investment incentives, revisions to utility planning procedures, establishment of codes and standards, and took an open minded view to new energy technologies. Utilities were told to include renewable energy capacity in their plans, and the state supported local jurisdictions that would take alternative energy initiatives.

With regard to the utility sector, California dictated how avoided costs were to be calculated, and the methodology established realistic prices for new energy supplies. The state went further to create several types of standard offer contracts for independent power producers of all sizes. Utilities were required to submit longer range forecasts and plans, and the state itself published an electric power outlook document every two years.

That the Public Utility Commission created standard offer contracts for independent energy producers greatly facilitated development of renewable energy projects. The long-term standard offer contracts guaranteed investors in renewable energy qualifying facilities purchase rates for the power for ten years. The earliest of these contracts, set during the 
period of high oil prices, reflected an expectation that oil prices would rise further; consequently, the long-term power purchase rates offered to independent energy producers were high. The contracts especially rewarded facilities that delivered energy during peak demand periods. In time, a moratorium was established for these types of contracts, an adjustment to a turn around in the price of oil. But even with this adjustment, the contracts are still being used to expand independent power production.

Short-term standard offer contracts that required quarterly revisions of the purchase price of qualifying facility energy were also available. These contracts allowed several renewable energy systems to continue to expand in the market, even after oil prices fell dramatically. These utility programs worked in conjunction with other factors to create a favorable environment fo: relatively unproven renewable energy technologies to flourish in the market. These other factors were:

o Financial incentives to help consumers and investors pay the higher initial capital cost of alternative energy systems

- Regulations that supported small-scale independent power production

- Abundant energy resources -- solar, wind, geothermal, biomass, small hydro, unused industrial process heat, energy convertible wastes

o Available capital and risk-taking entrepreneurs

o Increasing energy demand, often creating steep peaks

o High energy costs

o Active public intervention in utility affairs

o Responsive utility officials

The results were dramatic. Installed wind energy capacity in California grew from virtually nothing to 16,000 wind turbines totalling 1,400 megawatts of capacity. Through 1989, these turbines had generated 5,693 gigawatt hours of electricity, saving California the equivalent of 10,041,000 barrels of oil. In a state with 11 percent of the U.S. population, wind power was producing one percent of the electric power. ${ }^{9}$ For wind energy systems, existence of the early long-term Standard Offer \#4 contracts stimulated substantial cost reductions due simply to a high rate of installation. The cost reductions plus enhanced performance have enabled wind energy projects to continue to compete under the terms of the short-term standard offer contracts. This was also true for solar thermal electric projects.

The solar industry also grew in this time, primarily in the form of solar heating for buildings and solar thermal electric capacity. By 1982, 1500 companies were manufacturing and installing solar energy systems for buildings in California, generating $\$ 300$ to $\$ 350$ million

${ }^{9}$ Paul Gipe. Wind Energy Comes of Age in California. July, 1989. For "Wind Power Stations." John Wiley \& Sons. London. 1989. 
in sales. ${ }^{10}$ Luz International installed its first solar thermal electric power plant--SEGS I--in 1984, and now has a tolul of 275 megawatts of hybrid solar thermal/natural gas power plants on line and another 80 megawatt plant under construction. The biomass industry experienced a take-off, and a few megawatts of photovoltaic electric capacity have also been installed.

The power purchase contracts available in California allowed a variety of renewable energy technologies to compete with conventional resources. A mixture of pricing options allowed tailoring of revenue streams to the needs of various technologies while maintaining the same present value for a project. For example, higher rates paid to a qualifying facility in early years would be offset by lower rates paid in subsequent years. The turnover point was usually 10 years. Finally, the standard offer contracts accommodated a variety of technologies with pre-approvals that guaranteed cost recovery to utilities and lowered transactions costs of negotiating all the contract terms for the qualifying facility.

While the energy sales contracts were a very important factor, another ingredient for success was availability of state financial incentives in the form of tax credits, tax exemptions, and accelerated depreciation. In the early 1980s, 25 percent of the capital cost of a renewable energy system was returned to the investor as a federal tax credit, and an additional 25 percent was returnable as a California tax credit. Furthermore, 87.5 percent of the cost of the facilities could be depreciated in five years on federal taxes, and a similar provision existed for state tax payers. These financial incentives were a crucial part of a comprehensive strategy to attract capital and expand reliance on renewable energy technologies when they were in the earliest stages of commercial development.

Success in the market created further success because the high installation rates for the technologies in California furnished production and installation economies that lowered costs. In 1981, wind turbines cost between $\$ 2500$ and $\$ 3000$ per kilowatt installed and demonstrated capacity factors near 10 percent. By 1990, installed costs were less than $\$ 1000$ per kilowatt, and better siting and technical advances had raised the capacity factors of the best windfarms to 30 percent.

The installed cost per kilowatt of capacity for Luz International's solar thermal gas-hybrid electric power plants also fell a similar amount. It declined, in current dollars, from $\$ 4700$ per kilowatt in 1984 to $\$ 2875$ per kilowatt in 1989. A combination of technical advances and production economies account for this gain.

A few other factors must also be noted for the success in California. Many of the leading manufacturing and developer companies were located in the state. Their strong commitment to doing business in California caused them to devote resources to work for favorable laws and programs. Local governments also favored development of these

${ }^{10}$ California Energy Commission study on impacts of trx incentives. 
systems, and applied land use, public health and safety controls to encourage specific energy technologies. Land owners could raise more revenue by allowing multiple use of their holdings. This is particularly true for wind energy development. For solar electricity development, low cost land was available and suitable for development. Finally, electric utilities in the state were open enough to development of some of these technologies that they cooperated extensively with renewable energy developers during the introduction of the earliest systems.

California is not the only state where renewable energy technologies have enjoyed considerable success in the market. A similar expericnes occurred in New England. Solar heating for buildings expanded rapidly in the market because of a high dependence on petroleum and the large number of heating degree days in the region. As soon as oil prices rose quickly, building owners and state and local governments sought alternatives. Long a center of manufacturing, New England proved a ready host to the companies that began to produce solar energy equipment. These firms served local markets, as well as the rapidly growing one in California.

Biomass combustion for utility power has expanded rapidly in some New England states, notably in Maine. Several factors supported this expansion of wood energy. First, large forested areas provide an ample supply of fuel. Second, the lumber and paper and pulp industries were well established, and wood waste consumption for energy was already common because it was cheaper. Third, because of the pulp and paper industry, infrastructure for harvesting, marketing and transporting biomass already existed.

The most significant factor supporting expansion of biomass energy systems in Maine, however, was a series of actions taken by the Maine Public Utilities Commission. First, in 1981, the Commission adopted explicit rules governing small power production and cogeneration facilities. These rules and the accompanying order set forth a strong Commission policy encouraging development of these resources.

Second, in 1983, the Commission reviewed the practices of Maine's largest electric utility (Central Maine Power Company) in negotiating and acquiring resources from qualifying facilities. When the Commission found that the utility had not been following the Commission's policies, it reduced its rate of return. Third, in 1984, the Commission established standard long- term contracts and permitted substantial flexibility in the payment terms and payment patterns to accommodate different technologies.

Fourth, the Commission's least-cost planning practices compelled utilities to demonstrate that cogeneration and small power production facilities could not supply the necessary forecasted demand. Competitive bidding was established as the preferred way of demonstrating the availability of qualifying facilities

The result of these policies has been significant and rapid growth in renewable energy capacity. Maine currently has about 100 qualifying facilities, and in 1990 will obtain about 
20 percent of its total electricity supply from them. A significant majority of these facilities are renewable resource based (biomass, hydro, municipal solid waste). Counting energy projects currently under construction, by the end of 1991, Maine will receive about 30 percent of its electricity supply from qualifying facilities. This compares with roughly a two percent contribution from qualifying facilities in 1984.

Other states have also experienced success with biomass technologies. According to the National Wood Energy Association, by 1988, 3,800 megawatts of wood-fired electric power generation were on line at $\mathbf{2 9 6}$ facilities in $\mathbf{4 0}$ states. This is an increase from approximately 200 megawatts in 1980, when there were less than a dozen utilities in the U.S. with wood-fired power plants. The biomass contribution has grown rapidly, considering that it was only in 1983, that Washington Water Power Company brought on line the first modern-day wood fired electric power plant in Kettle Falls, Washington.

Other states besides California and Maine have renewable energy success stories to relate, both for centralized utility grid connected systems and dispersed renewable energy systems, primarily for buildings and commerce. With regard to utility regulation, five main factors standout. These are:

1) Clearly articulated commission policies and regulatory pricing decisions that reflected the particular operating characteristics of renewable energy systems.

2) Standard offer contracts with pricing options that met the needs of a wide range of renewable resource projects and compensated high value energy output.

3) An adequate renewable resource base well matched with demand profiles and need for new energy supplies.

4) Learning curve cost reductions due to high installation rates and associated technical advances.

5) A willing utility combined with an aggressive, competent manufacturer/developer of renewable energy technology possessing stamina to push past licensing and financing hurdles.

\section{KEY BARRIERS HINDERING RENEWABLE ENERGY DEVELOPMENT}

If renewable energy is so good, why isn't moving into the market faster?

One of the key barriers the seminar participants identified is the lack of information about the current cost and potential availability of renewable energy resources. Also lacking is knowledge about financing and contractual requirements of renewable energy technologies that differ from conventional energy systems. In short, one of the key barriers hindering 
faster development of these technologies is the requirement to learn about the attributes and capabilities of new systems. Assimilating enough information to gain a thorough understanding of all renewable energy technologies is a large order.

\section{First Key Barrier: Regulators do not have current and reliable information about cost, potential, availability, and development requirements of renewable energy resources.}

Utilities and regulators in most states do not have current information on the cost, potential and development requirements of renewable energy resources. Part of the reason is that the pace of technical and economic change for these technologies is rapid. For example, in 1990 the installed cost of complete parabolic trough collector systems for process heat applications is near \$22 per square foot. Such commercial systems installed in the early 1980s were near $\$ 50$ per square foot (in current dollars). This example of change is common for many renewable energy technologies and systems.

Another reason regulators lack information about renewable energy concerns the level of federal government support. Over the last ten years, federal government funds for renewable energy research and development declined from over $\$ 700$ million per year in 1980 dollars to under $\$ 120$ million in 1989 dollars. As the Department of Energy eliminated demonstration programs, transfer of information on performance of new systems nearly ceased. Moreover, government sponsored market research nearly vanished, further widening a data void.

Industry has not been able to fill the information void created by reduced federal government $\mathrm{R} \& \mathrm{D}$ budgets because it does not have the resources to represent itself in all the proceedings where it could present a case for renewable energy, nor has it the resources to conduct its own massive technology transfer programs. Thus, many utilities and commissions are simply unaware of the significant gains that have occurred technically and economically in the last few years.

Another reason utility regulators lack information is that most regulatory commissions have relatively small staffs and large case loads. Consequently, decision making generally takes place in the context of litigated proceedings, with decisions based on the record placed before the commission by the various parties in the case. If these parties do not focus on renewable energy, reliable and current information is not likely to come before the commission.

In many states where potential to develop renewable energy resources exists, renewable energy interests are under-represented in regulatory processes. Often, information that regulators could use that would enhance consideration of renewable energy is not flowing to them, or the packaging of that information, when it does arrive, is poor. Even where a sizable renewable or qualifying facility industry exists, these interests are reluctant to participate in adversarial proceedings against utilities that would be customers for their 
power. In addition, in a highly competitive market, rival firms are often reluctant to release detailed information that would actually be helpful to regulators.

Finally, other intervenors in regulatory proceedings cannot be counted on to provide the needed information. Interventions from environmental organizations often ignore and occasionally oppose renewable energy. For example, testimony from organizations concerned about the environmental impacts of air pollution and greenhouse gas emissions stress the need for more energy efficiency in the economy and consider any supply side alternatives a last resort. Only a few environmentally-oriented organizations are beginning to equate renewable energy sources of supply with energy efficiency.

A substantial finding from the Task Force seminar deliberations was that availability of reliable and regionally sensitive information on renewable energy resources is critical for removing regulatory barriers that inhibit more rapid deployment of the technologies that capture these resources. Different players, however, require different degrees of detail. For some, detailed discussions of least cost planning and pricing methodologies for setting avoided costs is important, for others, broader policy options are needed.

\section{What Information is Required?}

Quality, content, and design of information on renewable energy technologies is critical. Presentation must allow easy assimilation of information on potential supply, costs and reliability that is backed up with adequate detail to substantiate the data. This is particularly true when states adopt least cost planning methodologies. Least cost planning is a process than can help expand reliance on renewable energy resources, however, least cost planning depends on good information. Without accurate and trusted information, renewable resources will not do well in energy markets.

A primer on what is required to develop renewable energy resources and how those requirements need regulatory consideration must also be provided. Regulators need to know basic facts in order to establish rules and policies that do not discriminate against renewable energy. These include:

1) Payment terms associated with low fuel cost, high capital cost power plants.

2) Price structures that accommodate the operating characteristics of renewable energy systems.

3) The output and impacts on conventional energy systems of dispersed renewable energy systems.

4) The contribution of renewable energy that are not easily expressed in dollars, such as, risk reduction, fuel diversity, pollution reduction.

With regard to the environmental impacts of conventional energy systems. the key questions 
are, "What other costs to society exist and how much are they?" and, "How can these societal costs be used in decision making?"

The Task Force seminar did not devote much time to examining the issues and methodologies that are being developed to iricorporate externalities into utility and regulatory decision making. All agreed that consideration of externalities is important, but could be counter-productive if renewable energy technologies were perceived to need social cost adders in order to be competitive. This view reemphasizes the importance of having reliable and complete information on renewable energy resources available for utility regulators.

Second Key Barrier: Qualifying facility screening, pricing and contracting practices undervalue renewable energy resources; this barrier includes programs that miscalculate avoided costs due to overemphasis on near-term energy costs and bidding programs with the same bias.

The procedures used in many states to evaluate or select qualifying facilities tend to understate the value of many renewable energy resources. Methods used currently do a reasonably good job of capturing the economic value (or avoided cost) associated with more traditional types of resources. However, whether the process they use is competitive bidding, standard rate offers, or commission-established prices, the analytical methods employed in setting the prices or in ranking or evaluating bids generally do not take into account the very specific and very unique operating characteristics and lifetime costs of renewable energy resources.

Avoided costs are not a single value applicable to all types of added energy resources. Adding a solar energy facility would enable a utility to avoid different costs then those avoided if wind, coal or nuclear capacity of similar size were added. Thus, operating characteristics of each specific facility greatly influences the value, and hence, avoided cost associated with its addition to the utility grid. The calculation of avoided cost rates as currently performed in many states do not reflect these differences. Studies of the sensitivities to many of the key operating characteristics have shown variations in the values as high as 25 to 30 percent.

Even where overall levels of avoided cost are "properly" determined, translating the avoided cost into prices paid to qualifying facilities can unintentionally bias the selection against renewable resources. Pricing practices which do not freely permit the substitution of capital costs for fuel costs tend to favor facilities that are less capital-intensive and more fuel-intensive. Requiring avoided costs to be paid on a cents per kilowatt hour while ignoring credits paid per kilowatt of capacity, can have the same result.

A weak link in the least cost planning process is the availability of up- to-date information on the cost and performance of renewable energy technologies. Least cost planning is only an analytical process. The value of a least cost plan depends highly on the completeness 
and accuracy of the information used to develop it. If stale information understates the value of available renewable energy resources or overstates the cost of renewable energy systems, the least cost plan will call for a minor contribution from renewable energy. This conclusion is unchanged in states that rely on bidding or other mechanisms to develop resource plans.

In sum, utilities or regulators with inaccurate information on the cost and performance of renewable energy systems will reject renewable bids or claims by vendors. They require a thorough understanding of:

1) the analytical avoided cost methodologies,

2) the process translating avoided costs into prices paid to qualifying facilities, and

3 ) the implications of relying on renewable versus nonrenewable resources.

The same considerations that apply to administratively determined avoided costs processes also apply to bidding systems. Even in a bidding context, utilities or regulatory commissions must evaluate the bid on a facility-by- facility basis with due consideration for the characteristics of the systems. The value of those characteristics must be known before an informed decision can be made. "Cookbook" style bidding rules will generally be designed for the most traditional and typical generating facilities. Again, without adequate information when rules are initially instituted, they may unintentionally bias selections against renewable energy resources.

TABLE II-2

TECHNOLOGY BREAKDOWN IN WINNING BIDS

(May 1984 to May 1990)

\begin{tabular}{lcc} 
Technology & Capacity in MWe & Percent of Total \\
\cline { 2 - 3 } Natural gas & $3,171.6$ & 44.5 \\
Coal & $1,790.8$ & 25.0 \\
Municipal Wastes & 477.9 & 7.0 \\
Wood & 524.8 & 7.0 \\
Utility System Sales & 425.0 & 6.0 \\
Oil & 341.3 & 5.0 \\
Hydro & 89.2 & 1.3 \\
Geothermal & 23.0 & 0.3 \\
Wind & 22.0 & 0.3 \\
Demand Side Mgt & 117.2 & 1.6 \\
Other & 152.0 & 2.0
\end{tabular}

SOURCE: Current Competition Vol. 1, No. 1. Stockton, N.J. May 1990. 
For example, critics contend that many bidding systems put in place disfavor renewable energy systems because they give greater weight to low first cost systems and near-term energy costs. The results presented in Table II-2 suggest such an observation is true since non-renewable energy reso irces account for about 80 percent of thie capacity in projects that have won bids over the last six years.

A review of bidding rules and procedures was beyond the scope of this assessment, but such a review from the perspective of renewable energy technology developers would provide important information on how utility regulators value present and future energy costs and attributes of competing energy systems.

\section{Third Key Barrier: Utilities are disinterested or skeptical about faster deployment of renewable energy technologies.}

Resistance by utilities to investment and lack of interest in renewable energy resources are key barriers to faster deployment of renewable energy systems. Only a few utility companies in the United States have taken an active role in development of renewable energy technologies. A few companies are involved in consortia to develop certain technologies like photovoltaics or central receiver solar therrnal systems, but the number of such firms is quite small. At heart, the utility industry in the U.S. remains skeptical about the potential of renewable energy to compete and furnish reliable sources of energy in the near and mid-term.

Utility funding of renewable energy research and development is also lacking. Prior to the Reagan administration revisions in Department of Energy commercialization policy, many utilities were directly involved in DOE research projects that would culminate in demonstration facilities. This support ended, and today few utility scale projects exist that involve renewable energy systems. Just 31 companies participate in a somewhat informal Utility Renewable Resources Association, which meets three or four times annually to discuss renewable energy R\&D. A few years ago, the Electric Power Research Institute budget for renewable energy technologies was cut by as much as 40 percent.

Finally, utilities in many parts of the United States need to receive the same reliable and regionally specific information that regulators require if renewable energy technologies are to enter into their future plans. Information on cost, performance and availability of interconnected and dispersed renewable energy systems is often out of date, leaving utility perceptions too much influenced by early experience.

Fourth Key Barrier: Expiration or uncertainty about government incentives and terms that support renewable energy resource development. 
A number of states have many standard offer contracts in place with purchase rates tied to early 1980 energy prices that were much higher than today. Thus far, they have resisted suggestions that these contracts be reopened. Long-term contracts with guarantees about prices are critically important for renewable energy companies. They are still in an early development stage, and with low fossil fuel prices and unrealistic expectations about future energy costs determining avoided costs, these firms are generally just marginally competitive. States can create and sustain policies that prevent reopening contracts for negotiation of new prices and payments for independently produced power. It will be important for them to continue to hold this line.

Many renewable energy resources are competitive currently without consideration of externalities and without any special tax benefits or other subsidies. Wind energy systems continue to expand in the market. Residential solar systems are also being installed without the tax incentives that expired in 1985. Many other renewable energy resources are very close to being competitive and very modest tax or other incentives would close the gap they have compared to non-renewable resources. Encouraging the development of these resources leads to several benefits.

Among them are:

1) Institutional learning that will further lower costs

2) Improvement in national energy security

3) Improvement in the environment

4) Economic expansion

To encourage these technologies and win these gains, however, requires long term commitments. To avoid counterproductive situations that have industries coming and going, it is necessary to:

a) Provide equitable tax treatment or other incentives that level the playing field with non-renewable energy resources; and

b) Establish certainty about the long-life of such incentives.

Stable policies and consensus building to establish practices covering such items as front-end loaded contracts, determination of avoided costs and capacity credits, access to transmission, and terms governing failure to operate are very important to future deployment of renewable energy resources. For example, making successful arrangements for firm wheeling of power to a suitable purchaser can be a significant factor in the development of certain renewable energy technologies in particular locations. Establishing such precedents and sustaining them will strengthen the ability of renewable energy developers to bring their product on stream.

Almost any opinion poll taken will reveal broad popular support for the view that the United States should rely more on renewable energy. One such poll taken early in 1990 for 
three California firms (U.S. Windpower, Luz International and California Energy Company) determined that a large segment of the population would accept higher utility bills ( $\$ 5$ to $\$ 10$ per month) if they knew the funds would be devoted to expanding use of clean, renewable energy resources. Yet, this reservoir of goodwill is limited in value unless distinct, well conceived and targeted policies are enacted to take advantage of it. To summarize, there is no doubt that utility regulators can implement regulatory policy and recommend creation of other longer term policies that will encourage more reliance on sustainable energy resources.

\section{KEY PUBLIC POLICY LESSONS}

Misperceptions of or lack of knowledge about cost and performance of renewable energy resource technologies is a primary barrier to the development of these resources. Many renewable energy systems have matured and are now fully capable of contributing economically to energy supply without consideration of externalities or special tax benefits or other subsidies. Other technologies are very close to being competitive, and only require modest incentives or partial consideration of externalities to close the gap.

The Task Force seminar and assessment led to identification of five fundamental energy policy lessons. These were:

1. Regulatory policy strongly affects renewable energy development.

Several technologies have progressed substantially in the market due to innovative handling of regulatory and contractual requirements by states and utilities. Often it is the specific details required to complete energy sales contracts that weigh heavily on the ability of renewable energy projects to pass crucial financing and regulatory hurdles; consequently, those who propose changing regulatory procedures must be cognizant of the details involved in deploying renewable energy technologies.

2. Successful state implementation of a qualifying facility program is important for renewable energy resource developers; but this alone is not sufficient to guarantee deployment of renewable energy. Successful renewable energy development requires special attention to the cost and operating characteristics of the technologies. The designers of least cost planning, bidding and other programs and initiatives taken at the state level must understand and take these factors into consideration.

3. The rate of change in the cost and performance characteristics of renewable energy technologies generally exceeds the ability of regulatory institutions to track it. As a result, regulatory policy makers are often unaware of cost effective renewable energy potential.

4. Production and installation learning curve economies still figure prominently in determining the delivered cost of energy from renewable energy systems. Irrespective of research and development gains, utility regulations that simply help expand the rate of 
deployment of certain renewable energy technologies will lower their costs and expand reliance on renewable energy resources.

5. Reviews of renewable energy and utility regulation usually ignore small dispersed renewable energy technologies that produce electricity or substitute for it or other fuels and focus instead on technologies that supply power to the grid as a central power station. This bias leads to inadequate consideration of the contribution dispersed renewable energy systems could be making.

These five policy lessons help summarize some the observations made about development of renewable energy resources. They will be slightly expanded upon in the next section, in which consideration of these five policy lessons, the factors that have contributed to success, and those factors which still impede development of renewable energy technologies form the basis of a renewable energy agenda proposed to the National Association of Regulatory Utility Commissioners. 


\section{SECTION III}

\section{A RENEWABLE ENERGY AGENDA FOR NARUC}

The first two sections of this report described the current status of renewable energy technologies and the key factors that govern their progress in the market. Although substantial progress in the commercial application of renewable energy technologies has occurred in the past decade, positive actions by State utility regulators are needed to realize the full potential of renewables. To assist regulators, a Renewable Energy Agenda which reflects the policy lessons, successes and barriers described in this report is presented below. The program items and adjunct activities included in the Agenda may be undertaken in accord with the preferences of NARUC and individual State utility regulators. It is anticipated, however, that workshops and other adjunct activities will be conducted concurrently with the various program items.

There are five program items in the recommended agenda and several adjunct activities to complement the agenda.

\section{Program Item \# 1: INFORMATION NEEDS OF REGULATORS}

A most significant impediment to the development of renewable energy resources is lack of current information on the level of exploitable renewable energy resources and the cost, potential availability, and performance of renewable energy systems. Few are aware of recent and very significant improvements in cost and performance of solar thermal electric power plants, multiple wind turbine facilities, and geothermal and biomass energy power plants.

Without this information, utility regulators will make erroneous judgements about which potential resources receive serious consideration in integrated resource planning or in the formation of policies that will govern resource selection processes.

\section{RECOMMENDATION:}

A. NARUC should develop an information program designed for utility regulators and their staff. The key information need is for up-to-date technical and economic attributes of renewable energy systems and their performance in the field. The information should be disaggregated by region and be compiled at two levels of detail: one for initial policy consideration; a second for substantive analysis.

B. NARUC should prepare a model for the Department of Energy or other information related institution to use as a guide for the content and formatting of the information regulators need. 
C. NARUC should undertake to collect and disseminate annually a "State of Renewable Energy Resources" report consisting of current data on cost, availability, and performance of renewable energy technologies. The report should include references to vendors and developers with a track record in the industry. The data should be in a form and level of detail that is most useful to state regulators.

D. NARUC should hold conferences, workshops and seminars on issues surrounding renewable energy. These can be held separately or in conjunction with periodic Least-Cost Planning conferences and those meetings on external or social costs of energy production and consumption. The information generated should be formatted to complement the annual status report.

E. NARUC should prepare a report detailing the contractual and financing requirements of renewable energy projects or technologies, both central station and dispersed. Companies in the renewable energy business stress that it is the "details" which enable or prevent many renewable energy projects from proceeding successfully in current markets with current regulatory practices. The practical problems faced by developers or marketers of renewable energy systems must be well understood before procurement bidding and contractual requirements are imposed. An inventory of key contract terms and practices relevant to renewable energy project success, with special attention to the aspects of renewable energy development that attract or deter private sector investors will expand understanding of renewable energy technology requirements.

F. NARUC should explore the possibility of making data from the annual status report available through an on-line electronic data system.

\section{Program Item \# 2 INVENTORY OF IN-DEPTH CASE STUDIES}

Many specific practices states and utilities use to screen, price or contract with qualifying facilities produce substantial biases against renewable energy technologies. An inventory of information is needed on specific practices that affect renewable energy technologies in state energy markets under current regulatory procedures. In addition to regulatory practices, the degree of interest in renewable energy resources by utility companies is an important factor in how well renewable energy resources progress in energy markets.

\section{RECOMMENDATION:}

A. NARUC should undertake in-depth case studies to identify specific aspects of currerit regulatory practices that bias against selection of renewable energy resources to satisfy energy needs. The studies should review:

1) analytical procedures required to determine the value of many types of qualifying facilities, particularly renewable energy ones; 
2) restrictions on pricing that contain a bias against high capital cost, low operating cost facilities (e.g. limitations on the use of levelized or front end loaded contracts);

3) bidding, procurement and contractual practices which discourage bidders or project developers from offering renewable energy facilities due to imposition of excessive transaction costs and erroneous forecasts of future energy prices and availability;

4) discrimination against new technologies because they are considered unproven.

B. NARUC should identify six to twelve key states which have largely undeveloped renewable energy resources and prepare detailed case studies of the specific regulatory practices that could encourage more development of renewable energy technologies in those states.

C. NARUC should also review the role of utility companies in development of renewable energy resources. This review should examine:

1) equity placements in renewable energy manufacturing concerns;

2) financial support for research and development and demonstration programs and

1 iects;

3). direct purchase of renewable energy capacity;

4) support for marketing of dispersed renewable energy systems;

5) investment in renewables-based independent energy projects (QFs); and,

6) non-regulated subsidiary operations in the renewable energy field.

D. NARUC should ensure that its on-going efforts to explore the external costs of energy production and consumption be coordinated fully with its initiatives in the renewable energy field, and that information that is generated by the Renewable Energy Task Force be formatted appropriately and introduced into the externalities assessment processes underway at this time.

A "detail" growing in importance is the heightened interest on the part of state governments and regulators in the concept of social costs of energy. Renewable energy systems can compete without such determinations; however, little doubt exists that adjustments in energy pricing to account for external costs will favor the competitive posture of renewable energy resources and open more renewable resource reserves for exploitation. Consequently, it will be useful to include an evaluation of mechanisms to apply the results of external cost assessments and thereby encourage development of renewable energy technologies that entail much lower social cost burdens.

\section{Program Item \# 3: POTENTIAL OF DISPERSED RENEWABLE ENERGY SYSTEMS}

A promising, near-term application of renewable energy resources is use of dispersed 
systems in the building, commercial and industrial sectors for generating electrical or thermal energy for use on-site. These systems include solar building design, solar space conditioning and water heating systems, photovoltaic systems, micro-hydroelectric facilities, individual wind turbines, biofuel systems, and low temperature geothermal energy systems. Dispersed systems also include completely off-grid energy units to serve remotely located customers utilities find quite expensive to supply with power. Staff at the Pacific Gas \& Electric Company have already concluded that such systems are already economical in areas where line extensions in excess of one mile are required. Studies in Colorado reveal similar findings.

\section{RECOMMENDATION:}

A. NARUC should collect and disseminate information on the cost, availability and performance of on-site, dispersed renewable energy systems.

B. NARUC should conduct a study of how on-site renewable energy technologies are being incorporated in least cost planning methods, and if necessary, suggest methods for integrating these technologies in such planning disciplines.

C. NARUC should conduct a study on regulatory and utility barriers to expansion of small on-site electricity producing renewable energy technologies. This study is needed to anticipate expansion of photovoltaic, wind, solar thermal electric, and biomass electric technologies in the residential and commercial building sectors.

\section{Program Item \# 4: NEXT RENEWABLE ENERGY STATES}

A large number of factors, including technical readiness, cost, institutional support and physical resource bases affect market acceptance of renewable energy technologies. Development of renewable energy resources has occurred in an uneven pattern. In large part, the innovative action of a few states and utilities has been responsible for the substantial gains over the last decade.

Many states are not fully exploiting the potential they already have to use renewable energy resources. NARUC should consider creating an initiative designed expressly for regulators that would organize and deliver the experience and expertise of states that have already benefitted from commercialization of renewable energy technologies to those states on the threshold of using more renewable energy resources.

\section{RECOMMENDATION:}

A. NARUC should create a Next Renewable Energy States program designed to hasten development of renewable energy resources in those states where conditions are the most promising. Such a program would accelerate transfer of experience from states already 
using renewable energy resources to those with unrealized renewable energy potential.

B. NARUC should prepare a solicitation designed to implement the "Next Renewable Energy States" program. The program should seek expressions of interest from states wishing to receive such assistance. The states should be selected on the basis of available untapped renewable resources and an expressed willingness of the public utility commission to implement changes in rules and regulatory practices consistent with policy to encourage development of renewable energy resources.

C. NARUC should identify a team of individuals most knowledgeable about the regulatory, utility and technical underpinnings for successful renewable energy programs at the state level. The team of individuals would be trained in technology transfer as well as policy formation.

The expert team, funded by NARUC/DOE, would prepare and deliver to the key public and private sectors in the state a comprehensive set of policy options. Based on experience from other states, the expert team would also provide an assessment of the policy, political and economic implications of implementing those options for the selected states.

\section{Program Item \#5: ENVIRONMENTAL AND TAX LEGISLATION}

In addition to utility and regulatory policies, state tax and, more importantly, federal tax policy can provide strong financial incentives or disincentives for utilization of particular energy resources. While tax policies may be a useful adjunct to least-cost planning, they can also be a burden if they are inconsistent with energy policies.

\section{RECOMMENDATION:}

A. NARUC should conduct a review of the influence existing and proposed tax policies have on least-cost planning in general and renewable resource deployment in particular.

B. NARUC should conduct a review of the existing effects environmental policies are having on least cost planning and renewable resource deployment.

C. NARUC should recommend amendments to federal legislators if it finds that existing and forthcoming tax and environmental policies are inconsistent with energy policy that seeks to spur deployment of renewable energy resources.

\section{ADJUNCT EXPERTS WORKSHOPS}

It is also recommended that NARUC convene several experts workshops or seminars. These workshops would be used to support studies proposed or underway, gather 
information, and prepare guidance and material for other NARUC workshops and functions that should give more attention to renewable energy topics and issues. Attendance would be limited to individuals with substantial experience in the related fields of inquiry. NARUC should include representatives from the renewable energy industry and utilities in these expert workshops.

Three possible Expert Workshops are suggested:

\section{1) BIDDING AND RENEWABLE ENERGY}

An experts workshop on bidding programs and how they are affecting development of renewable energy can help identify how bidding can be made to accommodate renewable energy resources. Besides sixteen states conducting bidding, another thirteen are developing bidding rules or considering doing so in the future. The workshop would identify key issues and suggest detailed provisions that could be incorporated in bidding programs that would remedy disadvantages suffered by renewable energy technologies. A follow-on activity would be conducted to evaluate the policy options and prepare a more general presentation package for a regular NARUC meeting.

\section{2) LEAST COST PLANNING AND RENEWABLE ENERGY}

There are many aspects of least cost planning that may pose barriers to renewable energy development. An experts workshop would be convened to identify the least cost planning barriers and suggest solutions.

\section{3) EXTERNALITIES ASSESSMENTS AND RENEWABLE ENERGY}

There is rapid change occurring in development of methodologies to determine the real social costs of energy production and consumption. Proper accounting of how and where society pays these costs will lead to wider acceptance of renewable energy use. NARLC should conduct an experts workshop that reviews the relationship of renewable energy resources to the current trends in methodological approaches. The workshop would inform industry personnel about developments in this field and seek their reaction and input for the regulatory policy formation that will follow.

\section{OTHER RECOMMENDATIONS}

NARUC can suggest that other organizations undertake several other initiatives that would encourage the development of renewable energy resources. These include:

1) Representation in State Proceedings

Renewable energy interests are generally under represented or unrepresented in key state 
regulatory proceedings that result in utility commission policy. Greater representation of renewables would assure that all relevant information on the potential for the resources, the particular needs of renewable energy technologies and the implications of policy options under consideration are made available to commissions prior to the creation of policy. The Department of Energy should consider supporting interdisciplinary teams of experts (such teams should include representatives from industry) that can be made available upon request of state commissions to provide input to important policy setting procedures. The existence of such a resource will also help DOE and the renewable energy industry keep track of the important proceedings that are progressing.

\section{2) National Energy Strategy}

The new DOE National Energy Strategy will be formally released in early 1991. While NARUC has already provided input, the Renewable Energy Task Force should continue to review the new strategy for its treatment of renewable energy.

\section{3) Government Facilities}

Federal government conservation and renewable energy initiatives begun in 1990 include attention to energy use of government facilities. Such programs at the state level offer significant opportunities for expanding use of renewable energy technologies.

\section{4) Environmental Studies}

Federal and state government agencies that protect the environment should disseminate more information from power plant siting studies on renewable energy systems and their impact on the environment. This information is needed to help formulate policies on incorporation of externalities in energy decision making.

\section{5) Research and Development Funding}

Increases in the amount of federal government funding for renewable energy research and development will send important signals to the energy sector. The fiscal year 1991 budget for renewable energy $R \& D$ is expected to increase mociestly (as of mid-October the DOE appropriations bill had not yet emerged from congressional conference). States that also allocate more funding to support renewable energy research and development create a more positive attitude about renewable energy technologies and will attract more private sector interest.

In conclusion, there are three fundamental findings that form the basis of the renewable energy agenda presented above. These are:

1) Renewable energy resources have demonstrated competitiveness, and are making a 
substantial contribution to energy supply; but, very large untapped potential remains. Both centralized and dispersed renewable energy systems can play a major role in providing least cost energy resources with minimal environmental impact.

2) The key to the development of these resources lies in the hands of the states, and in particular, with state utility commissioners. Often, however, adequate information about renewable energy resources and their deployment is lacking.

3) The federal government can undertake initiatives that will accelerate development of renewable energy resources.

The conduct of this assessment represents a vital first step for NARUC to express its commitment to expansion of renewable energy resources in the United States. Accepting the renewable energy agenda set forth above will give NARUC the means to translate its commitment into concrete action. 


\section{Particlpants at the June, 1990 conference at SERI in Golden, CO}

The Hon. Henry G. Williams

New York PSC

Empire State Plaza

Albany, NY 12223

The Hon. Renz G. Jennings Arizona Corporation Commission 1200 West Washington Street

Phoenix, Arizona 85007

The Hon. Gary Nakarado Colorado Public Utilities Commission 1580 Logan Street

Denver, Colorado 80203

Mr. Carlo LaPorta

$R$ \& C Enterprises

6503 81st Street

Cabin John, MD 20818

Mr. Jim Cole

Georgla Public Service Commission

244 Washington Street SW

Atlanta, Georgla 30334

Dr. Barbara Combs

Oregon Publlo Utility Commission

300 Labor \& Industries Bldg.

Salem, Oregon 97310

Mr. Claude Eggleton

Ohio Public Utilities Commission

180 East Broad Street

Columbus, Ohio 43266-0573
Mr. Bill Meyer

California Public Utillties Commission

1107 9th Street \# 710

Sacramento, Callfornia 95814

Mr. David Illiff

Wisconsin Publio Service Commission

P.O. Box 7854

Madison, WI 53707

Mr. Larry DeWitt

New York Public Service Commission

Empire State Plaza

Albany, New York 12223

Ms. Janet Besser

New Hampshire PUC

8 Old Suncock Road

Concord, NH 03391

Mr. Mike Lotker

Luz Development \& Finance Corp.

924 Westwood Blvd. \#1000

Los Angelas, CA 90024

Mr. Carl Weinberg

Pacific Gas \& Electric Co.

3400 Crow Canyon Road

Concord, CA 94583

Mr. Ken Schafer

CE-141

U.S. Department of Energy

1000 Independence Ave., SW

Washington, DC 20585 
Participants at the June, 1990 conference at SERI in Golden, CO

Mr. Jim Rannels

CE-131

U.S. Department of Energy

1000 Independence Ave., SW

Washington, DC 20585

Mr. Blair Swezey

Solar Energy Research Institute

1617 Cole Boulevard

Golden, CO 80401

Mr. Sharif Fam

Thermo Electron Corporation

101-A 1st Avenue

Waltham, MA 02254

Mr. Alan Destribats

New England Electric System

25 Research Drive

Westborough, MA 01582

Mr. Robert Williams

Center for Energy \& Enviro. Studies

P.O. Box CN 5263

Princeton, NJ 08544-5263

Mr. L.G. Brackeen

Houston Lighting \& Power

P.O. Box 1700

Houston, TX 77002

Ms. Jan Hamrin

16 Channel Landing

Tiburon, CA 94920
Mr. James Rayburn

Savannah Electric

P.O. Box 968

Savannah, GA 31402

Mr. Mlke D'Angells

California Energy Commission

1516 9th Street

Sacramento, CA 95814

Mr. David Moskovitz

Energy Consultant

Hollywood Blvd.

Alna, ME 04535

Ms. Sue Cadenhead

CE-54

US Dept. of Energy

1000 Independence Avenue, SW

Washington, DC 20585

Mr. Mike Foley

Director of Financial Analysis

NARUC

P.O. Box 684

Washington, DC 20044

Mr. Larry Golden

Byrne, Slater, Sandler, Shulman, \& Rouse 330 Main Street

Hartford, CT 06106

Mr. Angus Duncan

Northwest Power Planning Council

505 C State Office Bldg.

Portland, OR 97201 